\title{
The 3.6 ka Aniakchak tephra in the Arctic Ocean: a constraint on the Holocene radiocarbon reservoir age in the Chukchi Sea
}

\author{
Christof Pearce $^{1,2}$, Aron Varhelyi ${ }^{1}$, Stefan Wastegård ${ }^{3}$, Francesco Muschitiello ${ }^{1,4,5}$, Natalia Barrientos ${ }^{1}$, \\ Matt O'Regan ${ }^{1}$, Thomas M. Cronin ${ }^{6}$, Laura Gemery ${ }^{6}$, Igor Semiletov ${ }^{7,8}$, Jan Backman $^{1}$, and Martin Jakobsson ${ }^{1}$ \\ ${ }^{1}$ Department of Geological Sciences and Bolin Centre for Climate Research, Stockholm University, \\ 10691 Stockholm, Sweden \\ ${ }^{2}$ Department of Geoscience, Aarhus University, 8000 Aarhus, Denmark \\ ${ }^{3}$ Department of Physical Geography and Bolin Centre for Climate Research, Stockholm University, \\ 10691 Stockholm, Sweden \\ ${ }^{4}$ Lamont-Doherty Earth Observatory, Columbia University, Palisades NY 10964-8000, New York City, NY, USA \\ ${ }^{5}$ Uni Research Climate, Bjerknes Centre for Climate Research, 5007 Bergen, Norway \\ ${ }^{6}$ U.S. Geological Survey, Reston, Virginia 20192, USA \\ ${ }^{7}$ Tomsk National Research Polytechnic University, Tomsk, Russia \\ ${ }^{8}$ Russian Academy of Sciences, Far Eastern Branch, Pacific Oceanological Institute, Vladivostok, Russia
}

Correspondence to: Christof Pearce (christof.pearce@geo.su.se)

Received: 3 November 2016 - Discussion started: 29 November 2016

Revised: 20 February 2017 - Accepted: 14 March 2017 - Published: 5 April 2017

\begin{abstract}
The caldera-forming eruption of the Aniakchak volcano in the Aleutian Range on the Alaskan Peninsula at $3.6 \mathrm{cal} \mathrm{kyr} \mathrm{BP}$ was one of the largest Holocene eruptions worldwide. The resulting ash is found as a visible sediment layer in several Alaskan sites and as a cryptotephra on Newfoundland and Greenland. This large geographic distribution, combined with the fact that the eruption is relatively well constrained in time using radiocarbon dating of lake sediments and annual layer counts in ice cores, makes it an excellent stratigraphic marker for dating and correlating midlate Holocene sediment and paleoclimate records. This study presents the outcome of a targeted search for the Aniakchak tephra in a marine sediment core from the Arctic Ocean, namely Core SWERUS-L2-2-PC1 (2PC), raised from $57 \mathrm{~m}$ water depth in Herald Canyon, western Chukchi Sea. High concentrations of tephra shards, with a geochemical signature matching that of Aniakchak ash, were observed across a more than $1.5 \mathrm{~m}$ long sediment sequence. Since the primary input of volcanic ash is through atmospheric transport, and assuming that bioturbation can account for mixing up to ca. $10 \mathrm{~cm}$ of the marine sediment deposited at the coring site, the broad signal is interpreted as sustained reworking at the sediment source input. The isochron is therefore placed
\end{abstract}

at the base of the sudden increase in tephra concentrations rather than at the maximum concentration. This interpretation of major reworking is strengthened by analysis of grain size distribution which points to ice rafting as an important secondary transport mechanism of volcanic ash. Combined with radiocarbon dates on mollusks in the same sediment core, the volcanic marker is used to calculate a marine radiocarbon reservoir age offset $\Delta R=477 \pm 60$ years. This relatively high value may be explained by the major influence of typically "carbon-old" Pacific waters, and it agrees well with recent estimates of $\Delta R$ along the northwest Alaskan coast, possibly indicating stable oceanographic conditions during the second half of the Holocene. Our use of a volcanic absolute age marker to obtain the marine reservoir age offset is the first of its kind in the Arctic Ocean and provides an important framework for improving chronologies and correlating marine sediment archives in this region. Core $2 \mathrm{PC}$ has a high sediment accumulation rate averaging $200 \mathrm{~cm} \mathrm{kyr}^{-1}$ throughout the last 4000 years, and the chronology presented here provides a solid base for high-resolution reconstructions of late Holocene climate and ocean variability in the Chukchi Sea. 


\section{Introduction}

The Arctic is currently in a state of rapid transition as a result of its sensitivity and amplified response to ongoing global climate warming (Johannessen et al., 2004; Screen and Simmonds, 2010; Serreze and Barry, 2011). The last few decades have seen increased freshwater input to the Arctic Ocean from rivers (Peterson et al., 2006), mass loss of glaciers and ice caps (Gardner et al., 2011), and, most notably, a dramatic loss of sea-ice cover (Cavalieri and Parkinson, 2012; Stroeve et al., 2014). The observed sea-ice loss is most pronounced in the western Arctic Ocean, i.e., in the Chukchi and Beaufort seas (Comiso, 2002). To put the observed changes in perspective, there is a strong need to investigate longer records of climatic and oceanographic variability from natural archives such as sediment cores. It is essential for this purpose to establish an accurate chronological framework that will allow correlation to other marine and terrestrial records and determine rates of change as well as leads and lags in the climate system. Besides the use of lead and cesium isotope dating for the most recent sediments, the standard approach for determining age and accumulation rates in Holocene sediments is the analysis of radiocarbon $\left({ }^{14} \mathrm{C}\right.$ ) content (Walker, 2005). The use of this method in the marine realm is complicated because of the spatial and temporal variability in the marine ${ }^{14} \mathrm{C}$ reservoir age $(R)$ (Reimer and Reimer, 2001). The reservoir age $R$ is a global average and represents the difference between the ${ }^{14} \mathrm{C}$ age of sea water and that of the contemporary atmosphere. This value $R$ is typically around 400 years, and is further complimented by a local correction, termed $\Delta R$ (Reimer and Reimer, 2001; Stuiver and Braziunas, 1993). This local value is obtained by comparison of the radiocarbon age of a marine sample with that of the atmosphere, but is limited to samples obtained before AD 1955, after which global ${ }^{14} \mathrm{C}$ levels increased due to nuclear bomb testing (Druffel and Linick, 1978). Although a number of pre-nuclear dated mollusks exist for the western Arctic (McNeely et al., 2006), these data are sparse and entirely limited to Alaskan coastal sites (Fig. 1). The only way to reconstruct values of the local reservoir age offset in the past is by obtaining absolute ages for specific horizons which can be compared to their measured radiocarbon age.

Another method used for dating sediment cores from the Arctic Ocean is the measurement of paleomagnetic secular variation, which relies on the movement of the Earth's north magnetic pole through time and its signature as remanent magnetization in sediments (Nowaczyk et al., 2001; StOnge and Stoner, 2011). Although this is a promising technique applied successfully to high-temporal resolution sediment cores from the western Arctic Ocean (Barletta et al., 2008; Lisé-Pronovost et al., 2009), low sediment accumulation rates across much of the central Arctic (Backman et al., 2004; Jakobsson et al., 2014) preclude the use of paleosecular variation as a dating tool. Furthermore, there is a longstanding problem associated with the interpretation of paleo-

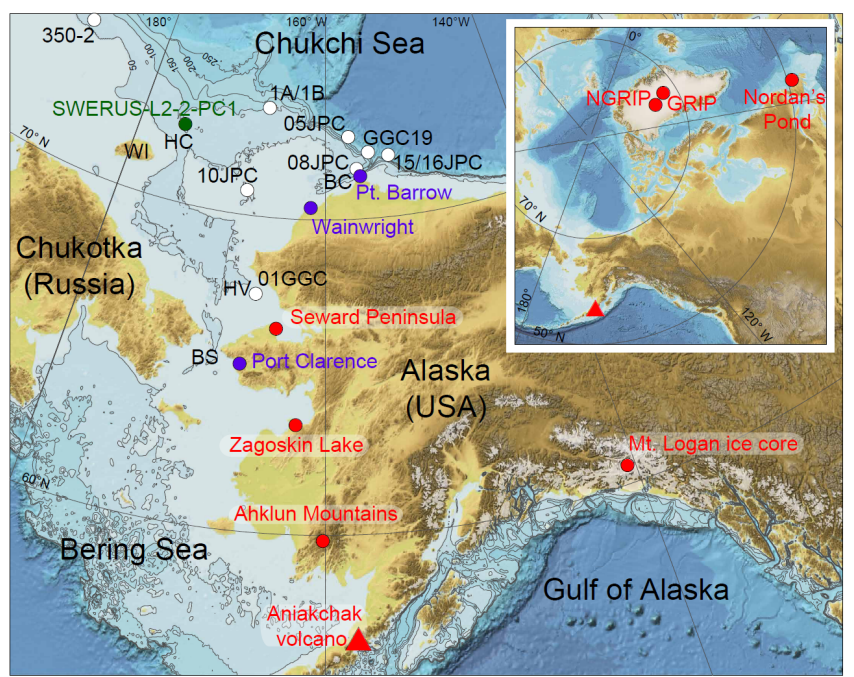

Figure 1. Map of study area and all sites mentioned in this study. Colors of markers - red: sites with Aniakchak CFE II tephra; blue: sites with modern $\Delta R$ data; white: marine sediment cores mentioned in the discussion; green: Core 2PC, subject of this study. Full core names with prefix in parentheses and references for site locations: (HLY0501-) 5JPC, (HLY0205-) 16JPC, (HLY0501-) 08JPC (Darby et al. 2009), (ARA2B-) 1A/1B, (PS272/) 350-2 (Stein et al., 2017), and (HLY0204-) 10JPC, (HLY0204-) 01GGC/02JPC, (HLY0205-) GGC19 (Keigwin et al., 2006). Other abbreviations: HC (Herald Canyon), WI (Wrangel Island), BC (Barrow Canyon), HV (Hope Valley), and BS (Bering Strait). Ocean bathymetry and land topography are from the General Bathymetric Chart of the Oceans, GEBCO (Weatherall et al., 2015), and the International Bathymetric Chart of the Arctic Ocean, IBCAO (Jakobsson et al., 2012).

magnetic records in the Arctic Ocean, in which rapid and frequent reversals in polarity do not seem to be correlated with known geomagnetic excursions or Chron boundaries (Backman et al., 2004; Channell and Xuan, 2009; Jakobsson et al., 2000; O'Regan et al., 2008).

Tephrochronology is a widely applied method that relies on the presence of volcanic ash that can be used for absolute dating (Lowe, 2011). Depending on the magnitude of a volcanic eruption and the chemical composition of its tephra deposits, ash layers can be used to correlate marine, terrestrial and ice-core records across thousands of kilometers. Reports of tephra in Arctic Ocean sediments are very scarce and consist of a study from the Fram Strait (Zamelczyk et al., 2012) and preliminary findings of tephra in the Chukchi Sea (Ponomareva et al., 2014). The aim of this study is to obtain an estimate of the local radiocarbon reservoir offset in the Chukchi Sea during the late Holocene. A marine sediment core from Herald Canyon with high sediment accumulation rates is used for this purpose by combining accelerator mass spectrometry (AMS) radiocarbon dates on mollusks from 14 different depths with the Aniakchak tephra of approximately 3600 cal yr BP as an absolute age marker. 


\subsection{Aniakchak}

The Aniakchak volcano of the Aleutian Range on the Alaskan Peninsula $\left(56.88^{\circ} \mathrm{N}, 158.15^{\circ} \mathrm{W}\right.$; Fig. 1) has been active throughout the Holocene, with two large calderaforming eruptions (CFE) and at least 40 smaller eruptions, the most recent one in AD 1931 (Bacon et al., 2014; Neal et al., 2000). The oldest of the two large postglacial explosive eruptions is known as Aniakchak CFE I and is not accurately dated, but occurred between 9500 and 7000 years ago (Bacon et al., 2014; Miller and Smith, 1987). The second large eruption, known as Aniakchak CFE II, which is the subject of this study, occurred around 3600 years ago and formed a $1 \mathrm{~km}$ deep and $10 \mathrm{~km}$ wide caldera (Miller and Smith, 1987). On a global scale this eruption was one of the largest during the Holocene, ejecting over $50 \mathrm{~km}^{3}$ of volcanoclastic material (Begét et al., 1992; Blackford et al., 2014). The resulting ash occurs as a visible sediment layer in large areas over northwestern Alaska (Begét et al., 1992; Blackford et al., 2014; Kaufman et al., 2012; Riehle et al., 1987) and as cryptotephra in the Mt. Logan Prospector-Russell Col ice core (Zdanowicz et al., 2014), Nordan's Pond bog in Newfoundland (Pyne-O'Donnell et al., 2012), and Greenland ice cores (Abbott and Davies, 2012; Coulter et al., 2012; Pearce et al., 2004) (Fig. 1). Preliminary data also indicate its presence in a marine sediment core from the Chukchi Sea margin (Ponomareva et al., 2014).

Since the ash occurs at many sites, estimates for its age have been obtained using different methods. The precise age of the Aniakchak CFE II eruption, however, is currently the subject of debate (Bacon et al., 2014; Blackford et al., 2014; Davies et al., 2016; Kaufman et al., 2012; Pearce et al., 2004). A recent review (Davies et al., 2016) concluded that the age of the event, based on all available radiocarbon dates, does not agree with the age obtained from the Greenland ice cores, where the age appears to be too old by several decades. Here we argue that the radiocarbon dates from the Alaskan lakes are in fact compatible with the icecore ages, when taking into account recent work that quantifies a possible offset between the IntCal13 radiocarbon timescale and the GICC05 ice-core timescale (Adolphi and Muscheler, 2016; Muscheler et al., 2014). Based on Adolphi and Muscheler (2016), the difference between the Greenland ice-core chronology and the radiocarbon calibration curve, expressed as IntCal13-GICC05, equals $-19 \pm 3$ years at $3600 \mathrm{cal} y \mathrm{BP}$. When taking the age of the eruption from the GRIP ice core as $3591 \pm 3$ cal yr BP (reported as $3641 \pm 3$ a b2k; Abbott and Davies, 2012), and incorporating the offset in timescale, the age becomes $3572 \pm 4$ cal yr BP on a timescale comparable with calibrated radiocarbon ages. This estimate of $3572 \pm 4$ cal yr BP is used in this study as the age of the Aniakchak CFE II ash layer. Davies et al. (2016) compiled all the available ${ }^{14} \mathrm{C}$ dates from the literature of sediment deposits containing the Aniakchak ash and critically assessed their reliability. Depending on which age constraints to include in the model, Davies et al. (2016) obtained age estimates for the Aniakchak CFE II ranging between 3300 and 3600 cal yr BP. A comparison of the ${ }^{14} \mathrm{C}$ dates from above and below the ash horizon selected by Davies et al. (2016) to the NGRIP age for the Aniakchak CFE II is listed in Table S1 and shown in Fig. S1 in the Supplement.

\subsection{Study site}

The Chukchi Sea is a marginal sea of the Arctic Ocean and covers the large shallow shelf bordered by Alaska to the east and the Chukotka Peninsula to the west (Fig. 1). It is separated from the Pacific Ocean by the Bering Strait, stretches over ca. $620000 \mathrm{~km}^{2}$ and has an average water depth of $80 \mathrm{~m}$ (Jakobsson, 2002). Sedimentation rates in this region are generally high and regularly exceed $150 \mathrm{~cm} \mathrm{kyr}^{-1}$ (Darby et al., 2009). The Chukchi Sea receives seasonally variable inflow of nutrient-rich waters of Pacific origin and is one of the most productive areas of the world ocean (Woodgate et al., 2005). Several paleoceanographic studies exist from this region (Barletta et al., 2008; Darby et al., 2009; Farmer et al., 2011; Keigwin et al., 2006; Polyak et al., 2016; Stein et al., 2017), but nearly all have focused on the eastern Chukchi Sea, off Alaska, simply because there are few sediment cores available from the western Chukchi Sea (Fig. 1). The sediment core used in this study is from Herald Canyon in the western Chukchi Sea, east of Wrangel Island (Fig. 1). Herald Canyon connects with the $50 \mathrm{~m}$ deep Bering Strait through a shallow bathymetric channel. The canyon begins to take a distinct form east of Wrangel Island and becomes more bathymetrically pronounced northward towards the continental shelf edge. It widens and loses the bathymetric expression at about $140 \mathrm{~km}$ before the northern shelf edge of the Chukchi Sea (Fig. 1). Herald Canyon hosts one of the main branches of Pacific waters traversing the Chukchi Shelf from the Bering Strait towards the Arctic Ocean shelf edge and its deeper basins (Pickart et al., 2010; Woodgate et al., 2005). The dominance of Pacific waters in this relatively shallow environment should be reflected in the local marine radiocarbon reservoir age, which is high ( $\Delta R>400$ years) in the north Pacific (Dumond and Griffin, 2002; Kuzmin et al., 2007). Few measurements of the reservoir age offset exist and those that do are entirely focused along the Alaskan coast in the Chukchi Sea (Fig. 1). Based on analyses of 11 bivalves clustered in three sites (Port Clarence/Teller, Wainwright, and Point Barrow; Fig. 1), an average value of $\Delta R=468 \pm 95$ was calculated for the eastern Chukchi Sea (McNeely et al., 2006; Reimer and Reimer, 2001). No data exist for the central or western Chukchi Sea.

\section{Materials and methods}

All results presented in this study are based on lithological, geochemical and microscopic analysis of samples from a single sediment core in the western Chukchi Sea. 
Table 1. Radiocarbon date list for core SWERUS-L2-2-PC1. All dates are calibrated using the Marine13 calibration curve (Reimer et al., 2013). The top two dates are reported in percent modern carbon (pMC) rather than years. BP: before present (AD 1950).

\begin{tabular}{|c|c|c|c|c|c|c|c|c|c|}
\hline \multirow[b]{2}{*}{$\begin{array}{l}\text { Depth } \\
(\mathrm{cm})\end{array}$} & \multirow[b]{2}{*}{ Lab ID } & \multirow[b]{2}{*}{ Material } & \multirow[b]{2}{*}{$\begin{array}{r}{ }^{14} \mathrm{C} \text { age } \\
(\mathrm{yr} \mathrm{BP})\end{array}$} & \multirow[b]{2}{*}{$\begin{array}{r}\text { Error } \\
\text { (years) }\end{array}$} & \multirow[b]{2}{*}{$\Delta R$} & \multicolumn{2}{|c|}{$\begin{array}{l}\text { Calibrated age range }(2 \sigma)- \\
\text { unmodeled }\end{array}$} & \multicolumn{2}{|c|}{$\begin{array}{l}\text { Modeled age } \\
\text { (cal yr BP) }\end{array}$} \\
\hline & & & & & & $\begin{array}{r}\text { from } \\
(\text { cal yr BP) }\end{array}$ & $\begin{array}{r}\text { To } \\
\text { (cal yr BP) }\end{array}$ & Mean & error \\
\hline 2.5 & Beta-439106 & Mollusk & $100.2 \mathrm{pMC}$ & $0.3 \mathrm{pMC}$ & - & 0 & -64 & -38 & 15 \\
\hline 10.5 & Beta-439107 & Mollusk & $101.1 \mathrm{pMC}$ & $0.3 \mathrm{pMC}$ & - & 0 & -64 & -18 & 18 \\
\hline 124 & Beta-425276 & Mollusk fragments & 1180 & 30 & $477 \pm 60$ & 491 & 234 & 356 & 44 \\
\hline \multirow[t]{3}{*}{233} & LuS11273 & Mollusk: Macoma sp. & 1630 & 35 & & & & & \\
\hline & Beta-400366 & Mollusk: Macoma sp. & 1610 & 30 & & & & & \\
\hline & Combined & & 1618 & 23 & $477 \pm 60$ & 803 & 613 & 720 & 38 \\
\hline 269.5 & Beta-425277 & Mollusk fragments & 1730 & 30 & $477 \pm 60$ & 922 & 670 & 866 & 41 \\
\hline 331 & Beta-425278 & Mollusk fragments & 2010 & 20 & $477 \pm 60$ & 1233 & 947 & 1196 & 47 \\
\hline 359 & Beta-409686 & Mollusk: Yoldia sp. & 2440 & 30 & $477 \pm 60$ & 1688 & 1356 & 1515 & 65 \\
\hline 383.5 & Beta-425279 & Mollusk fragments & 2720 & 30 & $477 \pm 60$ & 2026 & 1681 & 1793 & 64 \\
\hline 423 & NOSAMS-131231 & Mollusk: Macoma sp. & 3040 & 15 & $477 \pm 60$ & 2372 & 2056 & 2124 & 63 \\
\hline 543 & NOSAMS-131230 & Mollusk: Macoma sp. & 3460 & 20 & $477 \pm 60$ & 2925 & 2614 & 2755 & 47 \\
\hline 587 & LuS11274 & Mollusk: Yoldia sp. & 3645 & 45 & $477 \pm 60$ & 3162 & 2771 & 2967 & 56 \\
\hline \multirow{3}{*}{646.5} & LuS11275 & Mollusk: Macoma calcarea & 3895 & 40 & & & & & \\
\hline & Beta-400367 & Mollusk: Macoma calcarea & 3820 & 30 & & & & & \\
\hline & Combined & & 3847 & 25 & $477 \pm 60$ & 3371 & 3099 & 3259 & 51 \\
\hline 697.5 & LuS11276 & Mollusk: Macoma sp. & 4065 & 40 & $477 \pm 60$ & 3674 & 3326 & 3528 & 59 \\
\hline \multirow[t]{3}{*}{760.5} & LuS11277 & Mollusk: Macoma sp. & 4445 & 40 & & & & & \\
\hline & Beta-400368 & Mollusk: Macoma sp. & 4430 & 30 & & & & & \\
\hline & Combined & & 4435 & 25 & $477 \pm 60$ & 4113 & 3817 & 3915 & 63 \\
\hline
\end{tabular}

\subsection{Coring}

Core SWERUS-L2-2-PC1 (hereafter 2PC) is an $824 \mathrm{~cm}$ long piston core taken from $57 \mathrm{~m}$ water depth at $72.52^{\circ} \mathrm{N}$ $175.32^{\circ} \mathrm{W}$ in the Chukchi Sea (Fig. 1). The core was collected in August 2014 from R/V Oden during leg 2 of the SWERUS-C 3 expedition in the Arctic Ocean from Barrow (Alaska, USA) to Troms $\varnothing$ (Norway). The core site lies in Herald Canyon, $150 \mathrm{~km}$ northeast of Wrangel Island. The accompanying trigger weight core was retrieved empty. The sediment core was split lengthwise and described on board and later stored at $4{ }^{\circ} \mathrm{C}$ at the Department of Geological Sciences, Stockholm University.

\subsection{Radiocarbon chronology}

Accelerator mass spectrometry (AMS) radiocarbon measurements were made on mollusks from 14 different depths in Core 2PC (Table 1). From three samples, the mollusks were broken in half and sent to different radiocarbon laboratories to ensure reproducibility. This resulted in a total of 17 AMS measurements and 14 effectively dated horizons in the core (Table 1). Radiocarbon dates were converted to calendar ages using the Marine13 calibration (Reimer et al., 2013) and the Oxcal 4.2 program (Bronk Ramsey, 2008, 2009). Initially a value of $\Delta R=400 \pm 400$ years was used for calibration because of the largely unknown marine radiocarbon reservoir age at the coring site. This approach resulted in an age-depth relationship with large uncertainties. However, this age model provided a first indication of the depth interval which should be studied in detail in order to find cryptotephra from the Aniakchak CFE II eruption. After identification of a tephra horizon, this information was fed back into the age-depth model, resulting in an estimate of $\Delta R$ with much higher precision. Subsequently, the improved $\Delta R$ estimate was used to construct the final radiocarbon age-depth model for Core 2PC.

\subsection{Tephra quantification}

Tephra concentrations in Core $2 \mathrm{PC}$ were determined between $546 \mathrm{~cm}$ and the bottom of the core at $824 \mathrm{~cm}$, specifically to target the Aniakchak CFE II eruption. This depth interval was chosen to ensure that sediments with an approximate age of $3600 \mathrm{cal} \mathrm{yr} \mathrm{BP}$ were included in the analysis, as well as older samples to quantify any possible background levels of tephra shards. A series of consecutive cuboid $50 \mathrm{~mm} \times 5 \mathrm{~mm} \times 5 \mathrm{~mm}$ samples were taken continuously between 546 and $824 \mathrm{~cm}$ from the working half of the core. This amounted to 56 samples that were freezedried and weighed before sieving and preparation following the methods described in Turney (1998). The samples were sieved through a $25 \mu \mathrm{m}$ mesh, after which the fraction having a density range between 2.3 and $2.5 \mathrm{~g} \mathrm{~cm}^{-3}$ was isolated using repeated steps of centrifuging with sodium polytungstate heavy liquid. Tablets with known concentrations of Lycopodium spores were added to the remaining fraction 

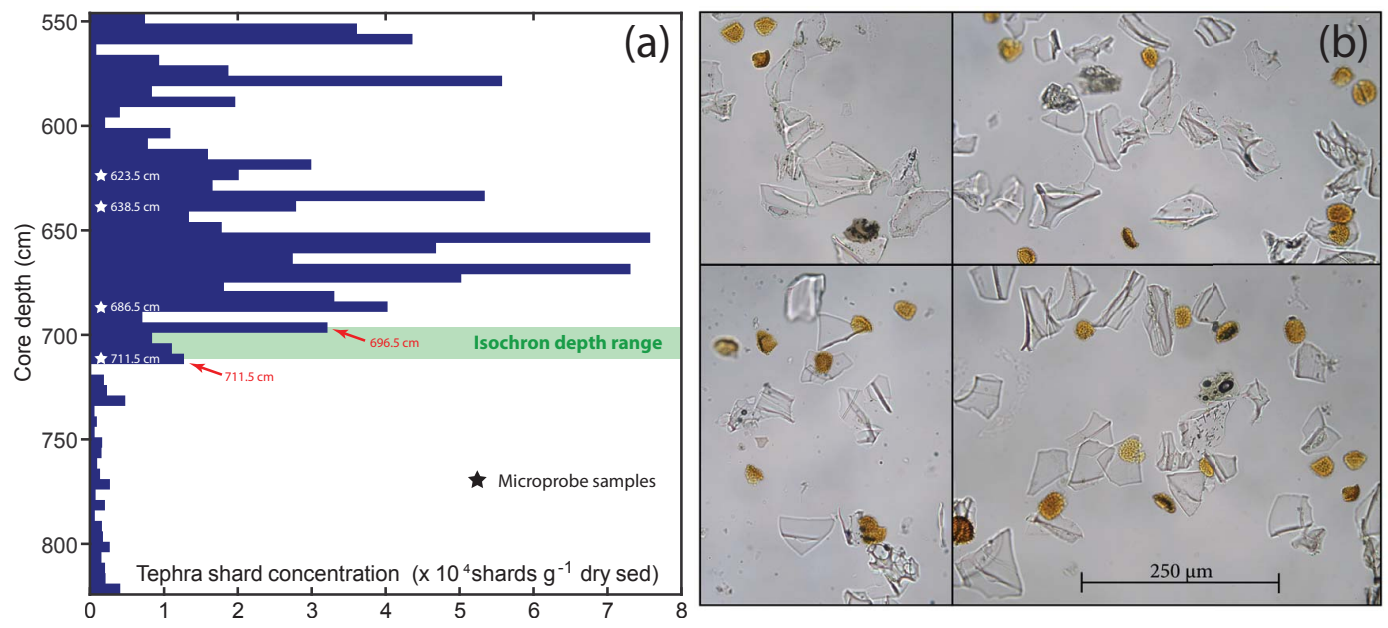

Figure 2. (a) Tephra concentrations in the lower sections of core 2PC. Red arrows point to minimum and maximum isochron depths for the Aniakchak CFE II tephra. Stars indicate samples analyzed for major oxide composition. (b) Light microscope images of tephra shards in samples from the same core. Brown palynomorphs are Lycopodium spores used for quantification.

together with a drop of hydrochloric acid solution to dissolve the tablet matrix. Finally, the material was mounted on microscope cover glasses using Canada balsam. Using a transmitted light microscope at $400 \times$ magnification, tephra particles were manually counted together with Lycopodium spores until 300 spores were counted per sample. The concentration of tephra shards was then calculated as shards per gram dry sediment, using the known concentration of $L y$ copodium spores, the ratio of shards to spores and the dry weight of the original sample.

\subsection{Major element geochemistry}

The major elemental composition of tephra shards was determined using an electron probe microanalyzer (EPMA) on selected samples. Material from four different depths (Fig. 2, Table 2) was mounted in epoxy on thin section slides, polished and coated with carbon prior to analysis. The measurements were made on a JXA-8530F JEOL Superprobe at Uppsala University using a $15 \mathrm{kV}, 4 \mathrm{nA}$ beam of $10 \mu \mathrm{m}$ diameter. Glass standards reported in Jochum et al. (2006) were analyzed for calibration and validation of the EPMA measurements and are listed in Table S6 in the Supplement. Concentrations of major elements expressed as oxides $\left(\mathrm{Na}_{2} \mathrm{O}, \mathrm{SiO}_{2}\right.$, $\mathrm{Al}_{2} \mathrm{O}_{3}, \mathrm{MgO}, \mathrm{K}_{2} \mathrm{O}, \mathrm{CaO}, \mathrm{TiO}_{2}, \mathrm{FeO}_{\text {tot }}, \mathrm{MnO}$, and $\mathrm{P}_{2} \mathrm{O}_{5}$ ) were obtained from 10 shards per sample (Tables 2 and $\mathrm{S} 3$ in the Supplement, Fig. 3). All measurements with total oxide percentages over $94 \%$ were included, and were normalized to $100 \%$ (Table 2, Fig. 3)

\subsection{Grain size analysis}

Analysis of grain size distribution was performed on a specific interval in the lower part of Core 2PC, based on the obtained profile of tephra concentrations. The aim was to in- vestigate a possible relationship between grain size distribution and tephra abundances by selecting an interval with both high and low concentrations of volcanic shards. Between 646 and $747 \mathrm{~cm}$ depth, grain size distributions from $2 \mu \mathrm{m}$ to $2 \mathrm{~mm}$ were measured on 86 bulk samples using a Malvern Mastersizer 3000 laser diffraction particle size analyzer at the Department of Geological Sciences, Stockholm University. Sampling resolution was $1 \mathrm{~cm}$ between 646 and $715 \mathrm{~cm}$ and $2 \mathrm{~cm}$ between 715 and $747 \mathrm{~cm}$. Before analysis, samples were treated with a sodium hexametaphosphate solution $(<10 \%)$ as dispersing agent and submerged in an ultrasonic bath to ensure full disaggregation of the particles.

\subsection{Calculation of the regional radiocarbon reservoir correction}

The combination of an absolute age marker from a volcanic eruption and radiocarbon age estimate is used to calculate the radiocarbon marine reservoir age. If the radiocarbon age estimate for the volcanic horizon is too old compared to the absolute age of eruption, a positive $\Delta R$ correction is needed, and vice versa. Based on the tephra concentrations in Core $2 \mathrm{PC}$, the most likely depth or depth range for the eruption was determined. This depth of the isochron marker is placed at the first major increase of tephra concentrations above background levels, while taking into account bioturbation as a potential mechanism for transporting tephra shards downcore (Griggs et al., 2015; Lowe, 2011). The isochron depth was subsequently assigned an absolute age $3572 \pm 4$ cal yr BP in the Oxcal age-depth model. By combining this age marker with the radiocarbon dates, the regional radiocarbon reservoir age $\Delta R$ was calculated by narrowing down the uncertainties on the prior estimate of this value. 

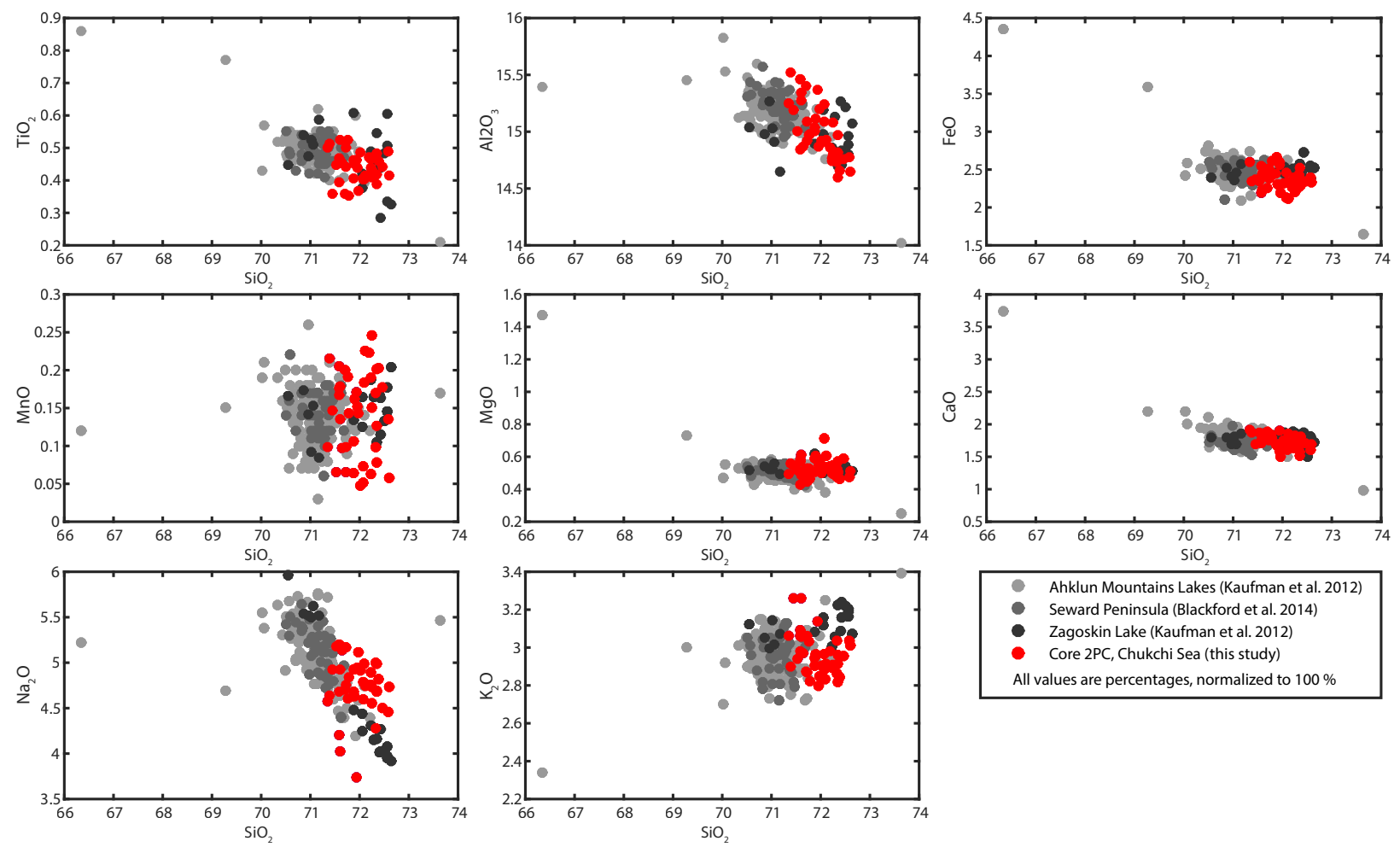

Figure 3. Major oxides compositions of tephra shards in core 2PC from the samples listed in Table 2, compared to data from the literature. All values are percentages, normalized to $100 \%$.

\section{Results}

\subsection{Radiocarbon}

The 14 AMS radiocarbon measurements do not contain any reversals or obvious outliers, and indicate a continuous sequence of nearly constant sediment accumulation rate (Table 1). The ages of duplicate measurements from different facilities on split mollusks (at 233.0, 646.5, and $760.5 \mathrm{~cm}$ ) returned fully consistent results within 1 standard deviation of error. The duplicate measurements from those samples were combined to slightly reduce the associated uncertainties of the obtained radiocarbon ages (Table 1). The two topmost samples contain radiocarbon content higher than "modern", indicating deposition after the onset of thermonuclear bomb testing during the 1950s. The radiocarbon analyses indicate that Core $2 \mathrm{PC}$ represents just over 4000 years of deposition with an average sediment accumulation rate of about $194 \mathrm{~cm} \mathrm{kyr}^{-1}$.

\subsection{Tephra abundance and composition}

Tephra was not observed through visual inspection or from smear slides of bulk sediment. Observations and quantifications of tephra, as described below, were based on microscopic studies of samples after sieving and density separation. Tephra shards observed in Core $2 \mathrm{PC}$ range in size from the minimum sieve size of 25 up to $340 \mu \mathrm{m}$, with the majority around $80 \mu \mathrm{m}$ in diameter. Shards are platy, clear, sometimes fluted, and with occasional crystal inclusions (Fig. 2). Tephra shards were present in all studied samples, although at widely varying concentrations. Counts varied from 2 to 1400 shards/300 Lycopodium spores, resulting in equivalent concentrations from 174 to 75000 shards per gram dry sediment (Fig. 2). Further upcore, tephra concentrations start low and vary around what is considered background levels until $711.5 \mathrm{~cm}$. Thereafter, concentrations increase sharply in a very broad $(>1 \mathrm{~m})$ peak, centered around $660 \mathrm{~cm}$. In the uppermost $50 \mathrm{~cm}$ of the investigated section $(546-600 \mathrm{~cm})$, concentrations fluctuate widely between background levels and peak maxima. The elemental oxide composition of the shards measured by EPMA is listed in Table 2 and shown in Fig. 3. All results from the four different depths show virtually identical geochemistry, which would indicate a common volcanic source for all measured ash shards (Fig. 3).

\subsection{Grain size distribution}

The grain size distribution is relatively constant throughout the investigated interval $(646-747 \mathrm{~cm})$ (Fig. 4). The distribution is dominated by the silt size fraction $(2-63 \mu \mathrm{m})$, which accounts for $84-87 \%$ of the grains in all 86 measured samples. The percentage of the clay fraction $(<2 \mu \mathrm{m})$ varies be- 

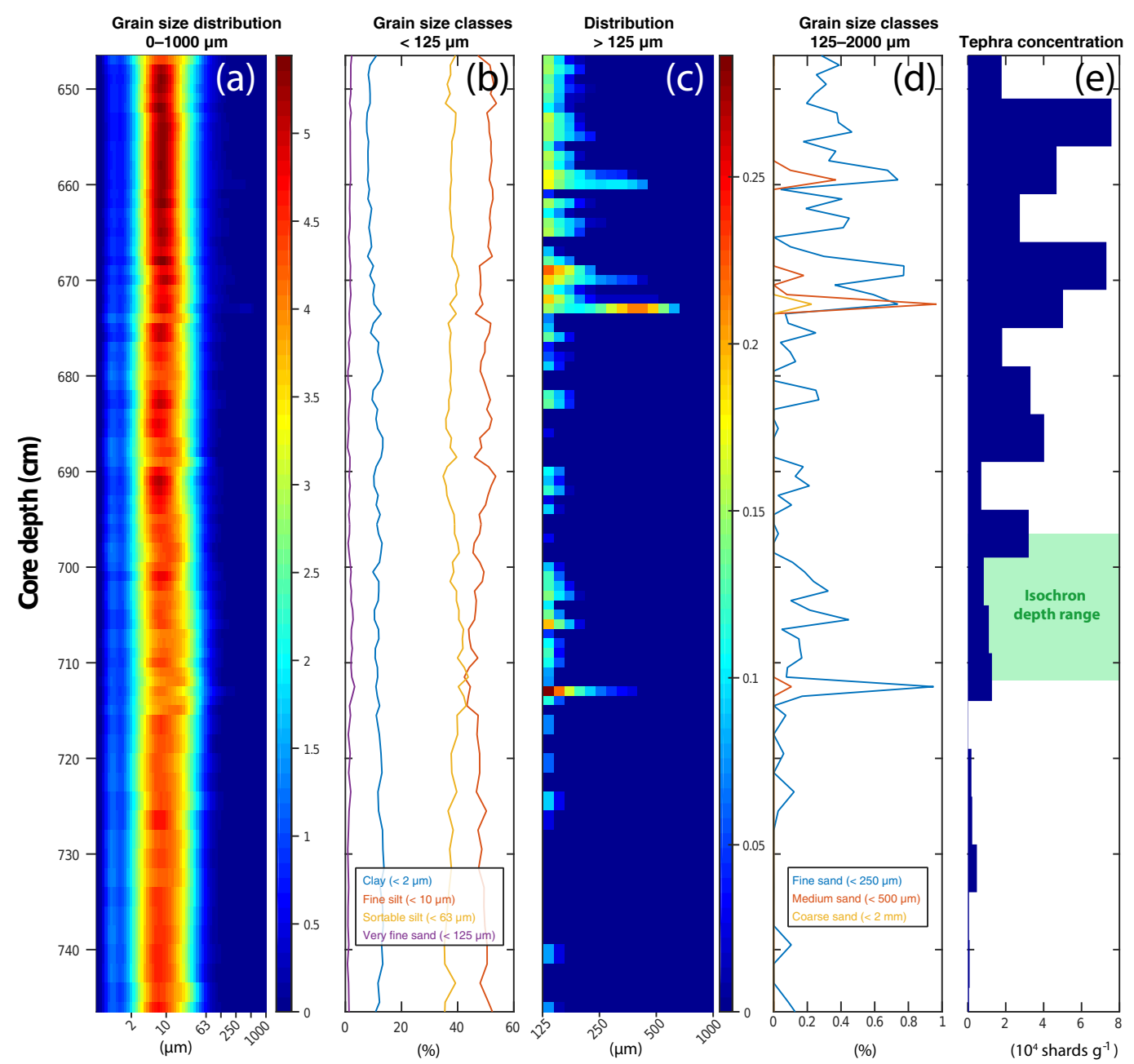

Figure 4. Grain size distribution (a-d) and tephra concentrations (e) between 640 and $750 \mathrm{~cm}$ depth in Core 2PC. (a) Full grain size range $(0-1 \mathrm{~mm})$ plotted as distribution percentages in a surface plot. (b) Grains $<125 \mu \mathrm{m}$ in categories. (c, d) Grain size distribution for grains $>125 \mu \mathrm{m}$ as surface (c) and categories (d). Note the different color scale values for the percentages between (a) and (c).

tween 7 and $14 \%$, whereas sand $(>63 \mu \mathrm{m})$ varies between 0.8 and $4 \%$ of the total grain size distribution. The size fractions of fine, medium and coarse sand are shown separately in Fig. 4 with the aim to identify possible presence of ice-rafted debris (IRD). Concentrations of shards larger than $125 \mu \mathrm{m}$ are low $(<1 \%)$ but appear to correlate with tephra concentrations, where tephra abundance maxima coincide with small increases in the presence of coarser-grained clasts (Fig. 4).

\section{Discussion}

\subsection{Identification of the Aniakchak tephra}

The geochemistry of the tephra shards in Core 2PC shows an excellent agreement with that of other, more proximal, deposits of the Aniakchak CFE II eruption. A comparison between all major oxide concentrations and those of the rhy- olitic, high-Si fraction of Aniakchak layers from several sites in Alaska (Fig. 1) is presented in Fig. 3. The $\mathrm{SiO}_{2}$ concentrations are towards the higher values (approximately 71.0$72.5 \%$ ), but still well within the range of the other datasets (approximately $70.0-72.5 \%$ ), and could potentially be explained by the different microprobes used in the individual studies. The reference data are from sediments of multiple lakes in the Ahklun Mountains (Kaufman et al., 2012), sediments of Zagoskin Lake on St. Michael Island (Davies et al., 2016), and an exposed peat section on the Seward Peninsula (Blackford et al., 2014). These sites all lie north to northeast of the Aniakchak volcano at distances of approximately 300, 760 , and $1100 \mathrm{~km}$, respectively, and all contain visible ash layers associated with the Aniakchak CFE II eruption. The thickness of the visible tephra beds decreases with distance from the source from more than $1 \mathrm{~m}$ of ash in lakes of the Ahklun Mountains (Kaufman et al., 2012) to $4-5 \mathrm{~mm}$ in the Seward Peninsula peat section (Blackford et al., 2014). Core 


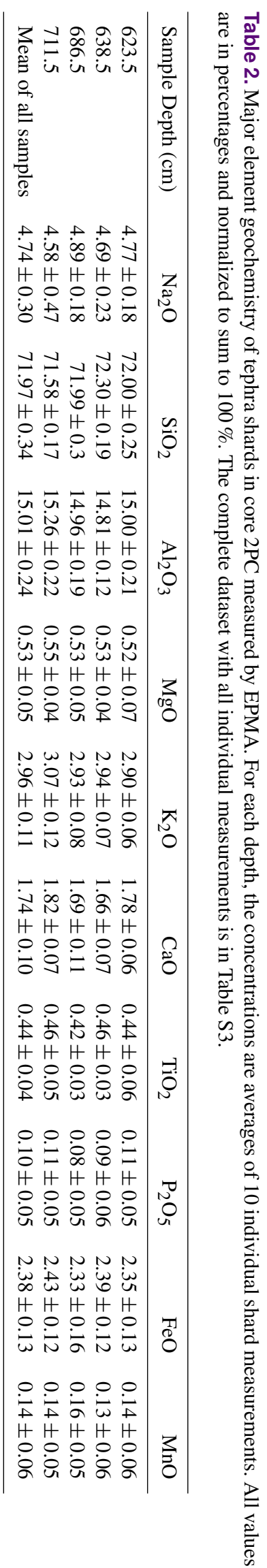

2PC in the Chukchi Sea lies in the extension of this line, approximately $1900 \mathrm{~km}$ from the proposed source (Fig. 1) and is thus likely a distal trap for volcanic material from the large $3.6 \mathrm{ka}$ eruption. This combination of matching geochemistry, geographic location and timing based on radiocarbon dates provides support for the identification of the Aniakchak CFE II tephra in Core 2PC. Although several smaller eruptions of the Aniakchak occurred in the Holocene (Bacon et al., 2014; Neal et al., 2000), they have not been associated with any tephra deposits. Kaufman et al. (2012) also identified a tephra layer of identical geochemistry at $3.1 \mathrm{cal} \mathrm{kyr} \mathrm{BP,} \mathrm{but}$ they could not establish whether this was a separate eruption or the result of widespread reworking of the earlier deposited tephra. Based on the data from marine Core 2PC, which shows continuous variable tephra deposition rather than a distinct second peak (Fig. 2), it is not possible to confirm the validity of these two options for the $3.1 \mathrm{kyr}$ BP tephra.

\subsection{Determination of the isochron depth}

When studying tephra deposits in sediments, one of the major challenges is to identify the isochron depth, i.e. the sediment layer corresponding to the timing of the volcanic eruption. This is especially true in marine environments where secondary processes can play a major role in redistributing sediments and obscuring the original signals (Griggs et al., 2015; Lowe, 2011). In an idealized setting, tephra particles are deposited after a volcanic eruption and rapidly buried and preserved, resulting in a clean marker horizon where the bottom contact is isochronous to the onset of the eruption. In reality, the tephra layer is often affected by bioturbation, which redistributes the tephra in the sediment column, as well as secondary transport mechanisms which can produce a delayed signal (Davies et al., 2010; Lowe, 2011). Despite these processes which broaden the tephra distribution, the primary direct deposition of tephra may remain to be the dominating input mechanism and would result in a peak concentration at the isochron depth (Lowe, 2011). If, however, the reworked signal dominates over the primary deposition, the peak tephra concentration may significantly lag the actual time of eruption.

Tephra was found in all studied samples of Core 2PC, which indicates that secondary processes should definitely be taken into consideration when interpreting the signal. Although the presence of tephra is continuous, there is significant variability in the actual concentrations and a clear background signal preceding the increase associated with the Aniakchak CFE II eruption. The highest peak of the tephra distribution in Core 2PC occurs at $653.5 \mathrm{~cm}$ depth (Fig. 2), which is $58 \mathrm{~cm}$ above the first major increase in tephra concentration above background levels at $711.5 \mathrm{~cm}$. The depth of the mean mixed layer has not been determined in Core 2PC, but other studies in the region observed mixing depths of 5-10 cm on the Chukchi Shelf (Baskaran and Naidu, 1995; Clough et al., 1997; McKay et al., 2008). These values are 

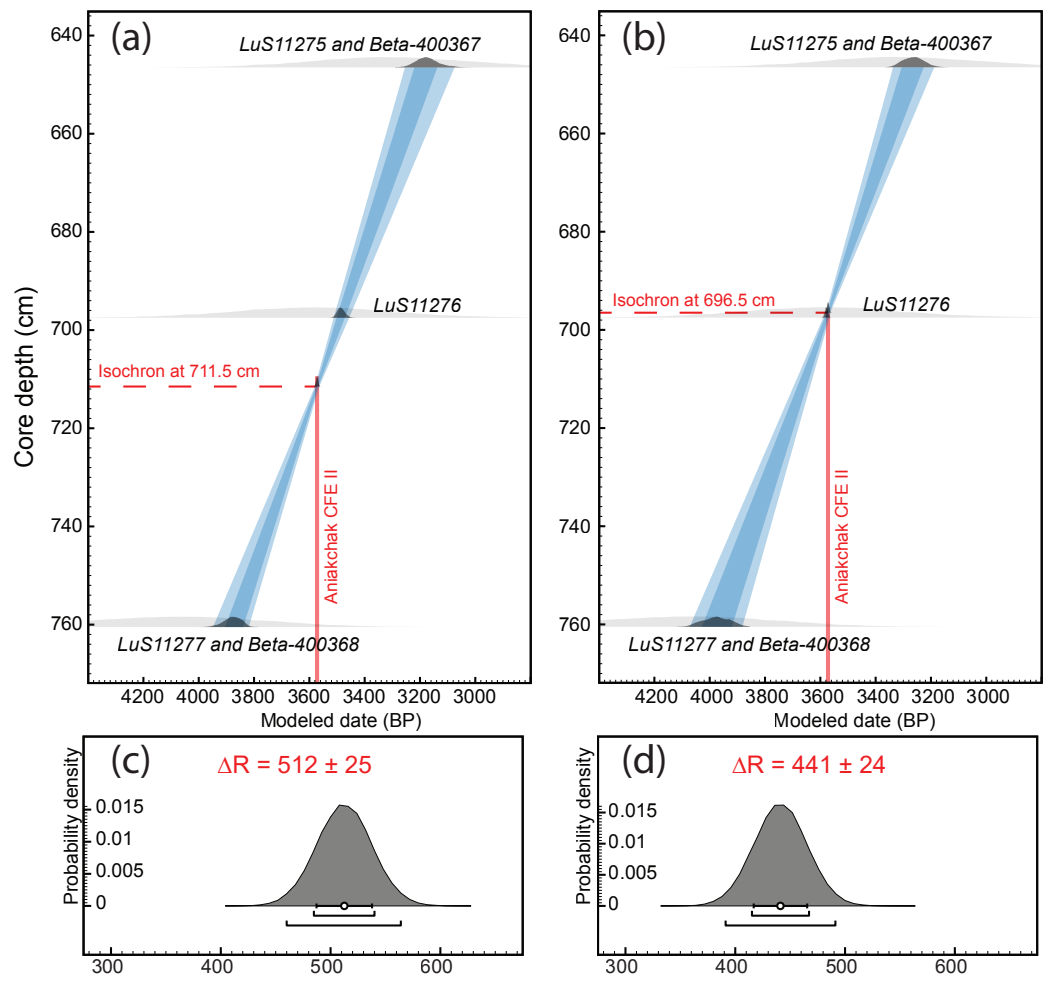

Figure 5. Calculation of marine reservoir age offset $\Delta R$, based on the placement of the isochron at different depths. (a, b) Age-depth models for the lower part of Core 2PC, based on maximum (a) and minimum (b) depth levels of the Aniakchak isochron. (c, d) Probability distribution of the posterior $\Delta R$ values for the maximum (c) and minimum (d) isochron depths.

well above the average maximum mixing depth of approximately $3 \mathrm{~cm}$ in the Arctic Ocean (Clough et al., 1997), and thus indicate that bioturbation may play a significant role in this environment. In Core 2PC, however, no visible traces of bioturbation were observed during visual inspection. Furthermore, a theoretical mixing depth of maximum $10 \mathrm{~cm}$ would not be able to explain an offset of $58 \mathrm{~cm}$ between the depths of first occurrence and peak tephra concentration. Since a downward redistribution of this magnitude caused by bioturbation is thus not possible in this environment, we argue that the deepest occurrence is the most likely depth for the eruption isochron.

Our placement of the isochron is thus based on the principle of first shard occurrence, although some mixing by bioturbation can not be ruled out entirely. To determine the uncertainty associated with our calculated reservoir age, we include a maximum mixing range of $15 \mathrm{~cm}$. When assuming a maximum bioturbation depth estimate of $15 \mathrm{~cm}$, this results in a depth range of the isochron from 711.5 to $696.5 \mathrm{~cm}$ (Fig. 2).

This interpretation thus also implies that the majority of tephra shards must have been delivered to the core site after the eruption by secondary processes, i.e. reworking of primary tephra deposits. The main transport mechanisms for this region are suspended and bed load transport by currents and sea-ice transport, either by suspension freezing or anchor ice formation (Darby et al., 2009). Grain size analysis can be useful in marine tephrochronology since anomalous patterns may be indicative of reworked sediments (Lowe, 2011). The grain size distribution in samples from Core 2PC shows that peaks of tephra concentration correspond to intervals with increased input of coarse material (Fig. 4). Despite the small concentrations of the coarser grain fractions, this correlation is a clear indicator of ice rafting during these intervals. This mechanism to transport tephra from distal primary deposits to the core site may explain the elevated tephra concentrations during these intervals.

Although similar lags between volcanic eruptions and tephra burial in sediments caused by secondary processes such as ice transport have been found in other studies from different regions (Austin et al., 1995; Brendryen et al., 2010; Lowe, 2011), our findings are the first report of geochemically identical tephra shards in more than $1 \mathrm{~m}$ of marine sediment. On the Hebridean Shelf off NW Scotland, Austin et al. (1995) placed the isochron depth for the Vedde ash layer at its first occurrence and argued for continuous reworking of larger-grained materials, explaining the peak ash concentration $20 \mathrm{~cm}$ higher in the core. With high sedimentation rates on the order of $1 \mathrm{~cm} \mathrm{yr}^{-1}$, however, this offset corresponded to only a few decades of temporal lag (Austin et al., 1995). A much larger difference was found by Brendryen et al. (2010), who observed an offset caused by iceberg rafting of several 
centuries between the eruption of volcanoes on Iceland and Jan Mayen and deposition of their tephra in the Norwegian Sea.

\subsection{Local radiocarbon reservoir age}

The offset between the age based on the radiocarbon age model and the absolute age of the volcanic eruption can be used to determine the reservoir age correction at the isochron depth (Ascough et al., 2005; Eiríksson et al., 2004; Olsen et al., 2014). Here, the volcanic age marker of $3572 \pm 4 \mathrm{calyr} \mathrm{BP}$ is added into the radiocarbon-based chronology using the Bayesian age-depth modeling software Oxcal 4.2 (Bronk Ramsey, 2009). The model includes a large uncertainty for the prior estimate of $\Delta R(=400 \pm 400$ years $)$, and, depending on the selected isochron depth and surrounding radiocarbon dates, the improved estimate for the local reservoir age offset will be the posterior probability of the $\Delta R$ value. This procedure is completed for two different possible Aniakchak isochron depths: the maximum depth, $711.5 \mathrm{~cm}$, and the minimum depth, $696.5 \mathrm{~cm}$, based on the maximum bioturbation estimate (Fig. 5). This backward modeling of the reservoir age resulted in posterior probability values of $\Delta R=512 \pm 25$ years and $\Delta R=441 \pm 24$ years, for the maximum and minimum isochron depths, respectively (Fig. 5). The maximum estimate for the mixing depth of $15 \mathrm{~cm}$ is less likely compared to shallower mixing, and therefore the probability distribution of the obtained $\Delta R$ will not be entirely symmetrical. However, to comply with conventional reporting of the radiocarbon reservoir age, the average value for the reservoir age is taken with an uncertainty to cover both extremes. The final estimate for the radiocarbon reservoir age offset at our core site, based on the presence of the Aniakchak CFE II tephra, is thus $\Delta R=477 \pm 60$ years.

This value represents the reservoir age at the time of the eruption and is not necessarily constant throughout the entire late Holocene. The calculated value, however, matches very well with the limited modern data available from mollusks collected before atmospheric radiocarbon contamination by testing of nuclear bombs in the 1950s (Druffel and Linick, 1978). A total of 11 such samples exist from the region, all from coastal Alaska: 4 offshore of Point Barrow, 3 south of Wainwright, and 4 just outside Teller on the other side of the Bering Strait (Fig. 1), with an average value of $468 \pm 95$ years (McNeely et al., 2006; Reimer and Reimer, 2001). These relatively high values of the reservoir age in this region both at present and earlier in the Holocene can be explained by the strong influence of Pacific water, which typically has an old radiocarbon content (McNeely et al., 2006; Ohkushi et al., 2007).

\subsection{Chronology of Core SWERUS-L2-2-PC1}

Since the depth of the tephra isochron is not precisely determined, but rather represented as a depth range, it is not

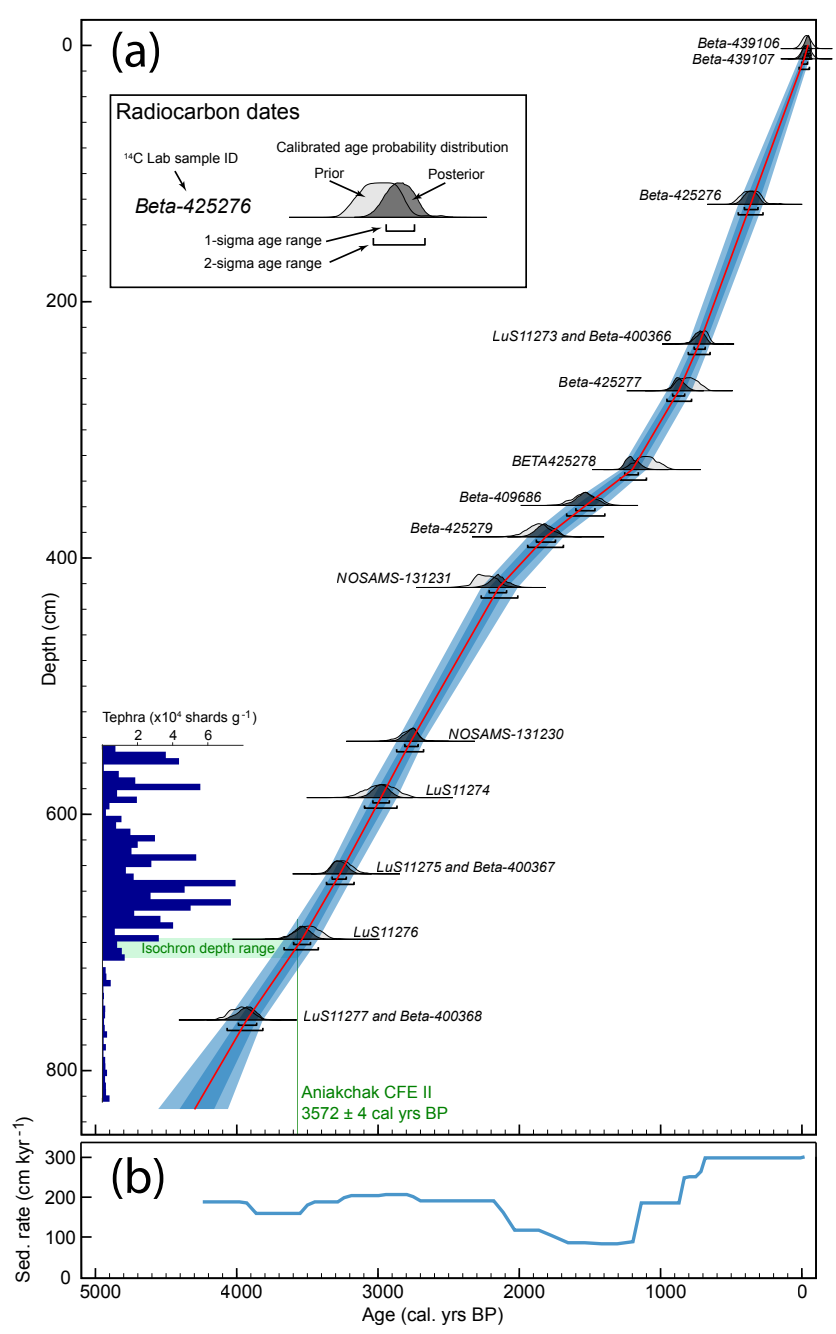

Figure 6. Final age-depth relationship (a) and sedimentation rates (b) of Core $2 \mathrm{PC}$ based on 17 radiocarbon dates (values in Table 1), using a $\Delta R=477 \pm 60$ years. In (a), the red line shows the median age and the dark- and light-blue shading show the $1 \sigma$ and $2 \sigma$ age ranges, respectively.

possible to include the absolute age marker with its associated low uncertainty directly into the age model. The final age model is therefore constructed based solely on radiocarbon dates and includes the Aniakchak CFE II indirectly by using a $\Delta R$ value calculated based on the possible depth range of the isochron. All radiocarbon dates are calibrated with $\Delta R=477 \pm 60$ years (Table 1) and the resulting age model is shown in Fig. 6. The topmost radiocarbon dates indicate a core top age estimate of AD $1995 \pm 15$ years and thus minimal loss of top sediments during piston coring. The age estimate at the bottom of the core $(824 \mathrm{~cm})$ is $4250 \pm 115$ cal yr BP, based on extrapolation below the deepest date at $760 \mathrm{~cm}$ (Fig. 6). Sediment accumulation rates are around $200 \mathrm{~cm} \mathrm{kyr}^{-1}$ for the oldest half of the core, after which they drop to approximately $100 \mathrm{~cm} \mathrm{kyr}^{-1}$ be- 
tween 2000 and 1200 cal yr BP. From there, a gradual increase again culminates in the highest sedimentation rates of $300 \mathrm{~cm} \mathrm{kyr}^{-1}$ during the most recent ca. 700 years (Fig. 6). In other sites of the Chukchi Sea, similar high sedimentation rates have been observed from the early Holocene and deglaciation, but rates typically decreased significantly during the late Holocene (Darby et al., 2009; Keigwin et al., 2006; Polyak et al., 2016). For the last 4000 years, Keigwin et al. (2006) reported sedimentation rates around $50 \mathrm{~cm} \mathrm{kyr}^{-1}$ in Core 19GGC near Barrow Canyon but about an order of magnitude lower rates in Core 10JPC from the central Chukchi Shelf and cores 01GGC and 02JPC from Hope Valley (Fig. 1). Other sedimentation rates for sites near Barrow Canyon reported by Darby et al. (2009) are $37 \mathrm{~cm} \mathrm{kyr}^{-1}$ in Core JPC8, $160 \mathrm{~cm} \mathrm{kyr}^{-1}$ in Core JPC5, and up to $250 \mathrm{~cm} \mathrm{kyr}^{-1}$ in Core JPC16 (Fig. 1).

\section{Concluding remarks}

Core SWERUS-L2-2-PC1 (2PC) from Herald Canyon in the Chukchi Sea contains a continuous sequence deposited at high sediment accumulation rates over the last 4250 years and has the potential to be used for studying late Holocene climate and ocean variability at decadal resolution in a region where no such data exist. The results presented here focus on a single volcanic eruption, the $3.6 \mathrm{ka}$ Aniakchak CFE II, in a single sediment core in the Chukchi Sea and therefore much work can be done to expand on this study. The upper half of the core contains potentially more volcanic age markers, although the tephra signal becomes more complex to interpret due to reworking of older eruptions. The earlier caldera-forming eruption of the Aniakchak volcano during the early Holocene, Aniakchak CFE I, may also be found in other records which extend further back in time. Based on our findings in Core 2PC and the geographic spread of the Aniakchak CFE II on land, this ash should also be present in other marine records of the Chukchi and Beaufort seas. If identified in other marine sediments from the region, the ash layer can be used as an age-equivalent marker between those sites and will greatly reduce the errors of their associated chronologies. Based on the presence of the Aniakchak CFE II tephra, the radiocarbon reservoir age $\Delta R$ at our site is calculated to be $477 \pm 60$ years, nearly identical to the best estimate of the present-day value for the wider region. This might be interpreted as an indication of a generally constant reservoir age in the Chukchi Sea throughout the second half of the Holocene. However, no data exist between 3600 cal yr BP and recent and so more absolute age markers would be necessary to strengthen this claim.

Data availability. All data presented in this manuscript can be found in the Supplement and will also be made available online through the Bolin Centre Database at http://bolin.su.se/data.

\section{The Supplement related to this article is available online at doi:10.5194/cp-13-303-2017-supplement.}

Competing interests. The authors declare that they have no conflict of interest.

Acknowledgements. Our gratitude goes to the entire crew and scientific party onboard R.V. Oden during Leg 2 of the 2014 SWERUS-C3 expedition. In particular, we wish to thank Carina Johansson for help with sampling and laboratory analyses. Many thanks to Abigail Barker of Uppsala University for her help with the microprobe analyses and the reporting of the standards. The research presented in this paper has received funding from the Knud and Alice Wallenberg Foundation, the Swedish Polar Secretariat, the US Geological Survey Climate R\&D program (T. Cronin, L. Gemery), the Russian Government (I. Semiletov: grant no. 14,Z50.31.0012/03.19.2014), and the Danish Council for Independent Research - Natural Sciences (C. Pearce DFF4002-00098_FNU). Any use of trade, firm, or product names is for descriptive purposes only and does not imply endorsement by the US Government.

Edited by: C. Barbante

Reviewed by: R. Stein, V. Ponomareva, and one anonymous referee

\section{References}

Abbott, P. M. and Davies, S. M.: Volcanism and the Greenland ice-cores: the tephra record, Earth-Sci. Rev., 115, 173-191, doi:10.1016/j.earscirev.2012.09.001, 2012.

Adolphi, F. and Muscheler, R.: Synchronizing the Greenland ice core and radiocarbon timescales over the Holocene - Bayesian wiggle-matching of cosmogenic radionuclide records, Clim. Past, 12, 15-30, doi:10.5194/cp-12-15-2016, 2016.

Ascough, P., Cook, G., and Dugmore, A.: Methodological approaches to determining the marine radiocarbon reservoir effect, Prog. Phys. Geogr., 29, 532-547, doi:10.1191/0309133305pp461ra, 2005.

Austin, W. E. N., Bard, E., Hunt, J. B., Kroon, D., and Peacock, J. D.: The ${ }^{14} \mathrm{C}$ Age of the Icelandic Vedde Ash: Implications for Younger Dryas Marine Reservoir Age Corrections, Radiocarbon, 37, 53-62, doi:10.1017/S0033822200014788, 1995.

Backman, J., Jakobsson, M., Løvlie, R., Polyak, L., and Febo, L. A.: Is the central Arctic Ocean a sediment starved basin?, Quaternary Sci. Rev., 23, 1435-1454, doi:10.1016/j.quascirev.2003.12.005, 2004.

Bacon, C. R., Neal, C. A., Miller, T. P., McGimsey, R. G., and Nye, C. J.: Postglacial eruptive history, geochemistry, and recent seismicity of Aniakchak volcano, Alaska Peninsula, US Geological Survey, available at: https://pubs.er.usgs.gov/publication/pp1810 (last access: 8 August 2016), 2014.

Barletta, F., St-Onge, G., Channell, J. E. T., Rochon, A., Polyak, L., and Darby, D.: High-resolution paleomagnetic secular variation and relative paleointensity records from the western Canadian Arctic: implication for Holocene stratigraphy and geo- 
magnetic field behaviour, Can. J. Earth Sci., 45, 1265-1281, doi:10.1139/E08-039, 2008.

Baskaran, M. and Naidu, A. S.: ${ }^{210} \mathrm{~Pb}$-derived chronology and the fluxes of ${ }^{210} \mathrm{~Pb}$ and ${ }^{137} \mathrm{Cs}$ isotopes into continental shelf sediments, East Chukchi Sea, Alaskan Arctic, Geochim. Cosmochim. Ac., 59, 4435-4448, doi:10.1016/00167037(95)00248-X, 1995.

Begét, J., Mason, O., and Anderson, P.: Age, Extent and Climatic Significance of the c. $3400 \mathrm{BP}$ Aniakchak Tephra, Western Alaska, USA, Holocene, 2, 51-56, doi:10.1177/095968369200200106, 1992.

Blackford, J. J., Payne, R. J., Heggen, M. P., de la Riva Caballero, A., and van der Plicht, J.: Age and impacts of the caldera-forming Aniakchak II eruption in western Alaska, Quaternary Res., 82, 85-95, doi:10.1016/j.yqres.2014.04.013, 2014.

Brendryen, J., Haflidason, H., and Sejrup, H. P.: Norwegian Sea tephrostratigraphy of marine isotope stages 4 and 5: Prospects and problems for tephrochronology in the North Atlantic region, Quaternary Sci. Rev., 29, 847-864, doi:10.1016/j.quascirev.2009.12.004, 2010.

Bronk Ramsey, C.: Deposition models for chronological records, Quaternary Sci. Rev., 27, 42-60, doi:10.1016/j.quascirev.2007.01.019, 2008.

Bronk Ramsey, C.: Bayesian Analysis of Radiocarbon Dates, Radiocarbon, 51, 337-360, doi:10.2458/azu_js_rc.v51i1.3494, 2009.

Cavalieri, D. J. and Parkinson, C. L.: Arctic sea ice variability and trends, 1979-2010, The Cryosphere, 6, 881-889, doi:10.5194/tc6-881-2012, 2012.

Channell, J. E. T. and Xuan, C.: Self-reversal and apparent magnetic excursions in Arctic sediments, Earth Planet. Sc. Lett., 284, 124131, doi:10.1016/j.eps1.2009.04.020, 2009.

Clough, L. M., Ambrose Jr., W. G., Kirk Cochran, J., Barnes, C., Renaud, P. E., and Aller, R. C.: Infaunal density, biomass and bioturbation in the sediments of the Arctic Ocean, Deep-Sea Res. Pt. II, 44, 1683-1704, doi:10.1016/S0967-0645(97)00052-0, 1997.

Comiso, J. C.: A rapidly declining perennial sea ice cover in the Arctic, Geophys. Res. Lett., 29, 1956, doi:10.1029/2002GL015650, 2002.

Coulter, S. E., Pilcher, J. R., Plunkett, G., Baillie, M., Hall, V. A., Steffensen, J. P., Vinther, B. M., Clausen, H. B., and Johnsen, S. J.: Holocene tephras highlight complexity of volcanic signals in Greenland ice cores, J. Geophys. Res.-Atmos., 117, D21303, doi:10.1029/2012JD017698, 2012.

Darby, D. A., Ortiz, J., Polyak, L., Lund, S., Jakobsson, M., and Woodgate, R. A.: The role of currents and sea ice in both slowly deposited central Arctic and rapidly deposited ChukchiAlaskan margin sediments, Global Planet. Change, 68, 58-72, doi:10.1016/j.gloplacha.2009.02.007, 2009.

Davies, L. J., Jensen, B. J. L., Froese, D. G., and Wallace, K. L.: Late Pleistocene and Holocene tephrostratigraphy of interior Alaska and Yukon: Key beds and chronologies over the past 30,000 years, Quaternary Sci. Rev., 146, 28-53, doi:10.1016/j.quascirev.2016.05.026, 2016.

Davies, S. M., Wastegård, S., Abbott, P. M., Barbante, C., Bigler, M., Johnsen, S. J., Rasmussen, T. L., Steffensen, J. P., and Svensson, A.: Tracing volcanic events in the NGRIP icecore and synchronising North Atlantic marine records during the last glacial period, Earth Planet. Sc. Lett., 294, 69-79, doi:10.1016/j.eps1.2010.03.004, 2010.

Druffel, E. M. and Linick, T. W.: Radiocarbon in annual coral rings of Florida, Geophys. Res. Lett., 5, 913-916, doi:10.1029/GL005i011p00913, 1978.

Dumond, D. E. and Griffin, D. G.: Measurements of the Marine Reservoir Effect on Radiocarbon Ages in the Eastern Bering Sea, Arctic, 55, 77-86, 2002.

Eiríksson, J., Larsen, G., Knudsen, K. L., Heinemeier, J., and Símonarson, L. A.: Marine reservoir age variability and water mass distribution in the Iceland Sea, Quaternary Sci. Rev., 23, 22472268, doi:10.1016/j.quascirev.2004.08.002, 2004.

Farmer, J. R., Cronin, T. M., de Vernal, A., Dwyer, G. S., Keigwin, L. D., and Thunell, R. C.: Western Arctic Ocean temperature variability during the last 8000 years, Geophys. Res. Lett., 38, L24602, doi:10.1029/2011GL049714, 2011.

Gardner, A. S., Moholdt, G., Wouters, B., Wolken, G. J., Burgess, D. O., Sharp, M. J., Cogley, J. G., Braun, C., and Labine, C.: Sharply increased mass loss from glaciers and ice caps in the Canadian Arctic Archipelago, Nature, 473, 357-360, doi:10.1038/nature10089, 2011.

Griggs, A. J., Davies, S. M., Abbott, P. M., Coleman, M., Palmer, A. P., Rasmussen, T. L., and Johnston, R.: Visualizing tephra deposits and sedimentary processes in the marine environment: The potential of X-ray microtomography, Geochem. Geophy. Geosy., 16, 4329-4343, doi:10.1002/2015GC006073, 2015.

Jakobsson, M.: Hypsometry and volume of the Arctic Ocean and its constituent seas, Geochem. Geophy. Geosy., 3, 1-18, doi:10.1029/2001GC000302, 2002.

Jakobsson, M., Løvlie, R., Al-Hanbali, H., Arnold, E., Backman, J., and Mörth, M.: Manganese and color cycles in Arctic Ocean sediments constrain Pleistocene chronology, Geology, 28, 2326, doi:10.1130/0091-7613(2000)28<23:MACCIA>2.0.CO;2, 2000.

Jakobsson, M., Mayer, L., Coakley, B., Dowdeswell, J. A., Forbes, S., Fridman, B., Hodnesdal, H., Noormets, R., Pedersen, R., Rebesco, M., Schenke, H. W., Zarayskaya, Y., Accettella, D., Armstrong, A., Anderson, R. M., Bienhoff, P., Camerlenghi, A., Church, I., Edwards, M., Gardner, J. V., Hall, J. K., Hell, B., Hestvik, O., Kristoffersen, Y., Marcussen, C., Mohammad, R., Mosher, D., Nghiem, S. V., Pedrosa, M. T., Travaglini, P. G., and Weatherall, P.: The International Bathymetric Chart of the Arctic Ocean (IBCAO) Version 3.0, Geophys. Res. Lett., 39, L12609, doi:10.1029/2012GL052219, 2012.

Jakobsson, M., Andreassen, K., Bjarnadóttir, L. R., Dove, D., Dowdeswell, J. A., England, J. H., Funder, S., Hogan, K., Ingólfsson, Ó., Jennings, A., Krog Larsen, N., Kirchner, N., Landvik, J. Y., Mayer, L., Mikkelsen, N., Möller, P., Niessen, F., Nilsson, J., O'Regan, M., Polyak, L., Nørgaard-Pedersen, N., and Stein, R.: Arctic Ocean glacial history, Quaternary Sci. Rev., 92, 40-67, doi:10.1016/j.quascirev.2013.07.033, 2014.

Jochum, K. P., Stoll, B., Herwig, K., Willbold, M., Hofmann, A. W., Amini, M., Aarburg, S., Abouchami, W., Hellebrand, E., Mocek, B., Raczek, I., Stracke, A., Alard, O., Bouman, C., Becker, S., Dücking, M., Brätz, H., Klemd, R., de Bruin, D., Canil, D., Cornell, D., de Hoog, C.-J., Dalpé, C., Danyushevsky, L., Eisenhauer, A., Gao, Y., Snow, J. E., Groschopf, N., Günther, D., Latkoczy, C., Guillong, M., Hauri, E. H., Höfer, H. E., Lahaye, Y., Horz, K., Jacob, D. E., Kasemann, S. A., Kent, A. J. 
R., Ludwig, T., Zack, T., Mason, P. R. D., Meixner, A., Rosner, M., Misawa, K., Nash, B. P., Pfänder, J., Premo, W. R., Sun, W. D., Tiepolo, M., Vannucci, R., Vennemann, T., Wayne, D., and Woodhead, J. D.: MPI-DING reference glasses for in situ microanalysis: New reference values for element concentrations and isotope ratios, Geochem. Geophy. Geosy., 7, Q02008, doi:10.1029/2005GC001060, 2006.

Johannessen, O. M., Bengtsson, L., Miles, M. W., Kuzmina, S. I., Semenov, V. A., Alekseev, G. V., Nagurnyi, A. P., Zakharov, V. F., Bobylev, L. P., Pettersson, L. H., Hasselmann, K., and Cattle, H. P.: Arctic climate change: observed and modelled temperature and sea-ice variability, Tellus A, 56, 328-341, doi:10.1111/j.1600-0870.2004.00060.x, 2004.

Kaufman, D. S., Jensen, B. J. L., Reyes, A. V., Schiff, C. J., Froese, D. G., and Pearce, N. J. G.: Late Quaternary tephrostratigraphy, Ahklun Mountains, SW Alaska, J. Quaternary Sci., 27, 344-359, doi:10.1002/jqs.1552, 2012.

Keigwin, L. D., Donnelly, J. P., Cook, M. S., Driscoll, N. W., and Brigham-Grette, J.: Rapid sea-level rise and Holocene climate in the Chukchi Sea, Geology, 34, 861-864, doi:10.1130/G22712.1, 2006.

Kuzmin, Y. V., Burr, G. S., Gorbunov, S. V., Rakov, V. A., and Razjigaeva, N. G.: A tale of two seas: Reservoir age correction values $(R, \Delta R)$ for the Sakhalin Island (Sea of Japan and Okhotsk Sea), Nucl. Instrum. Meth. B, 259, 460-462, doi:10.1016/j.nimb.2007.01.308, 2007.

Lisé-Pronovost, A., St-Onge, G., Brachfeld, S., Barletta, F., and Darby, D.: Paleomagnetic constraints on the Holocene stratigraphy of the Arctic Alaskan margin, Global Planet. Change, 68, 85-99, doi:10.1016/j.gloplacha.2009.03.015, 2009.

Lowe, D. J.: Tephrochronology and its application: A review, Quat. Geochronol., 6, 107-153, doi:10.1016/j.quageo.2010.08.003, 2011.

McKay, J. L., de Vernal, A., Hillaire-Marcel, C., Not, C., Polyak, L., and Darby, D.: Holocene fluctuations in Arctic sea-ice cover: dinocyst-based reconstructions for the eastern Chukchi Sea, Can. J. Earth Sci., 45, 1377-1397, doi:10.1139/E08-046, 2008.

McNeely, R., Dyke, A. S., and Southon, J. R.: Canadian marine reservoir ages, preliminary data assessment, available at: http://geoscan.ess.nrcan.gc.ca/cgi-bin/ starfinder/0 path=geoscan .fl\&id=fastlink \&pass $=\&$ search $=\mathrm{R} \%$ 3D221564\&format=FLFULL (last access: 17 February 2015), 2006.

Miller, T. P. and Smith, R. L.: Late Quaternary caldera-forming eruptions in the eastern Aleutian arc, Alaska, Geology, 15, 434438, doi:10.1130/0091-7613(1987)15<434:LQCEIT>2.0.CO;2, 1987.

Muscheler, R., Adolphi, F., and Knudsen, M. F.: Assessing the differences between the IntCal and Greenland ice-core time scales for the last 14,000 years via the common cosmogenic radionuclide variations, Quaternary Sci. Rev., 106, 81-87, doi:10.1016/j.quascirev.2014.08.017, 2014.

Neal, C. A., McGimsey, R. G., Miller, T. P., Riehle, J. R., and Waythomas, C. F.: Preliminary volcano-hazard assessment for Aniakchak Volcano, Alaska, USGS Numbered Series, U.S. Geological Survey, Reston, VA, available at: http://pubs.er.usgs.gov/ publication/ofr00519 (last access: 24 August 2016), 2000.

Nowaczyk, N. R., Frederichs, T. W., Kassens, H., NørgaardPedersen, N., Spielhagen, R. F., Stein, R., and Weiel, D.: Sedi- mentation rates in the Makarov Basin, central Arctic Ocean: A paleomagnetic and rock magnetic approach, Paleoceanography, 16, 368-389, doi:10.1029/2000PA000521, 2001.

Ohkushi, K., Uchida, M., Aoki, K., Yoneda, M., Ikehara, K., Minoshima, K., Kawahata, H., Tada, R., Murayama, M., and Shibata, Y.: Radiocarbon Marine Reservoir Ages in the Northwestern Pacific off Hokkaido Island, Japan, During the Last Deglacial Period, Radiocarbon, 49, 963-968, 2007.

Olsen, J., Rasmussen, T. L., and Reimer, P. J.: North Atlantic marine radiocarbon reservoir ages through Heinrich event $\mathrm{H} 4$ : a new method for marine age model construction, Geol. Soc. Sp. London, 398, SP398.2, doi:10.1144/SP398.2, 2014.

O’Regan, M., King, J., Backman, J., Jakobsson, M., Pälike, H., Moran, K., Heil, C., Sakamoto, T., Cronin, T. M., and Jordan, R. W.: Constraints on the Pleistocene chronology of sediments from the Lomonosov Ridge, Paleoceanography, 23, PA1S19, doi:10.1029/2007PA001551, 2008.

Pearce, N. J. G., Westgate, J. A., Preece, S. J., Eastwood, W. J., and Perkins, W. T.: Identification of Aniakchak (Alaska) tephra in Greenland ice core challenges the 1645 BC date for Minoan eruption of Santorini, Geochem. Geophy. Geosy., 5, Q03005, doi:10.1029/2003GC000672, 2004.

Peterson, B. J., McClelland, J., Curry, R., Holmes, R. M., Walsh, J. E., and Aagaard, K.: Trajectory Shifts in the Arctic and Subarctic Freshwater Cycle, Science, 313, 1061-1066, doi:10.1126/science.1122593, 2006.

Pickart, R. S., Pratt, L. J., Torres, D. J., Whitledge, T. E., Proshutinsky, A. Y., Aagaard, K., Agnew, T. A., Moore, G. W. K., and Dail, H. J.: Evolution and dynamics of the flow through Herald Canyon in the western Chukchi Sea, Deep-Sea Res. Pt. II, 57, 5-26, doi:10.1016/j.dsr2.2009.08.002, 2010.

Polyak, L., Belt, S. T., Cabedo-Sanz, P., Yamamoto, M., and Park, Y.-H.: Holocene sea-ice conditions and circulation at the Chukchi-Alaskan margin, Arctic Ocean, inferred from biomarker proxies, Holocene, 26, 1810-1821, doi:10.1177/0959683616645939, 2016.

Ponomareva, V., Polyak, L., Portnyagin, M., Abbott, P. M., and Davies, S. M.: A Holocene cryptotephra record from the Chukchi margin: the first tephro-stratigraphic study in the Arctic Ocean, Proceedings of the 2nd Past Gateways international conference and workshop, Trieste, 2014.

Pyne-O’Donnell, S. D. F., Hughes, P. D. M., Froese, D. G., Jensen, B. J. L., Kuehn, S. C., Mallon, G., Amesbury, M. J., Charman, D. J., Daley, T. J., Loader, N. J., Mauquoy, D., Street-Perrott, F. A., and Woodman-Ralph, J.: High-precision ultra-distal Holocene tephrochronology in North America, Quaternary Sci. Rev., 52, 6-11, doi:10.1016/j.quascirev.2012.07.024, 2012.

Reimer, P. J. and Reimer, R. W.: A marine reservoir correction database and on-line interface, Radiocarbon, 43, 461-463, doi:10.1017/S0033822200038339, 2001.

Reimer, P. J., Bard, E., Bayliss, A., Beck, J. W., Blackwell, P. G., Bronk Ramsey, C., Grootes, P. M., Guilderson, T. P., Haflidason, H., Hajdas, I., Hatté, C., Heaton, T. J., Hoffmann, D. L., Hogg, A. G., Hughen, K. A., Kaiser, K. F., Kromer, B., Manning, S. W., Niu, M., Reimer, R. W., Richards, D. A., Scott, E. M., Southon, J. R., Staff, R. A., Turney, C. S. M., and Plicht, J. van der: IntCal13 and Marine13 Radiocarbon Age Calibration Curves 0-50,000 Years cal BP, Radiocarbon, 55, 1869-1887, doi:10.2458/azu_js_rc.55.16947, 2013. 
Riehle, J. R., Meyer, C. E., Ager, T. A., Kaufman, D. S., and Ackerman, R. E.: The Aniakchak tephra deposit, a late Holocene marker horizon in western Alaska, US Geological Survey Circular, 998, 19-22, 1987.

Screen, J. A. and Simmonds, I.: The central role of diminishing sea ice in recent Arctic temperature amplification, Nature, 464, 1334-1337, doi:10.1038/nature09051, 2010.

Serreze, M. C. and Barry, R. G.: Processes and impacts of Arctic amplification: A research synthesis, Global Planet. Change, 77, 85-96, doi:10.1016/j.gloplacha.2011.03.004, 2011.

Stein, R., Fahl, K., Schade, I., Manerung, A., Wassmuth, S., Niessen, F., and Nam, S.-I.: Holocene variability in sea ice cover, primary production, and Pacific-Water inflow and climate change in the Chukchi and East Siberian Seas (Arctic Ocean), J. Quaternary Sci., doi:10.1002/jqs.2929, online first, 2017.

St-Onge, G. and Stoner, J.: Paleomagnetism Near the North Magnetic Pole: A Unique Vantage Point for Understanding the Dynamics of the Geomagnetic Field and Its Secular Variations, Oceanography, 24, 42-50, doi:10.5670/oceanog.2011.53, 2011.

Stroeve, J. C., Markus, T., Boisvert, L., Miller, J., and Barrett, A.: Changes in Arctic melt season and implications for sea ice loss, Geophys. Res. Lett., 41, 1216-1225, doi:10.1002/2013GL058951, 2014.

Stuiver, M. and Braziunas, T. F.: Sun, ocean, climate and atmospheric ${ }^{14} \mathrm{CO}_{2}$ ?: an evaluation of causal and spectral relationships, Holocene, 3, 289-305, doi:10.1177/095968369300300401, 1993.
Turney, C. S. M.: Extraction of rhyolitic component of Vedde microtephra from minerogenic lake sediments, J. Paleolimnol., 19, 199-206, 1998.

Walker, M.: Quaternary Dating Methods, 1st Edn., Wiley, Chichester, West Sussex, England, 2005.

Weatherall, P., Marks, K. M., Jakobsson, M., Schmitt, T., Tani, S., Arndt, J. E., Rovere, M., Chayes, D., Ferrini, V., and Wigley, R.: A new digital bathymetric model of the world's oceans, Earth Space Sci., 2, 331-345, doi:10.1002/2015EA000107, 2015.

Woodgate, R. A., Aagaard, K., and Weingartner, T. J.: A year in the physical oceanography of the Chukchi Sea: Moored measurements from autumn 1990-1991, Deep-Sea Res. Pt. II, 52, 3116-3149, doi:10.1016/j.dsr2.2005.10.016, 2005.

Zamelczyk, K., Rasmussen, T. L., Husum, K., Haflidason, H., Vernal, A. de, Ravna, E. K., Hald, M., and Hillaire-Marcel, C.: Paleoceanographic changes and calcium carbonate dissolution in the central Fram Strait during the last $20 \mathrm{ka}$, Quaternary Res., 78, 405-416, doi:10.1016/j.yqres.2012.07.006, 2012.

Zdanowicz, C., Fisher, D., Bourgeois, J., Demuth, M., Zheng, J., Mayewski, P., Kreutz, K., Osterberg, E., Yalcin, K., Wake, C., Steig, E. J., Froese, D., and Goto-Azuma, K.: Ice Cores from the St. Elias Mountains, Yukon, Canada: Their Significance for Climate, Atmospheric Composition and Volcanism in the North Pacific Region, Arctic, 67, 35-57, doi:10.14430/arctic4352, 2014. 